\title{
Multiple sclerosis in the Orkney and Shetland Islands
}

\section{$\mathrm{V}$ : The effect on viral titres of histocompatibility determinants}

DAVID C. POSKANZER, JOHN L. SEVER, PAUL I. TERASAKI, LEWIS B. PRENNEY, JEAN L. SHERIDAN, AND MIN SIK PARK

From the Neuroepidemiology Unit, Neurology Service, Massachusetts General Hospital, Boston, the Department of Neurology, Harvard Medical School, Boston, the Infectious Disease Branch, National Institute of Neurological and Communicative Disorders and Stroke, Bethesda, and the Department of Surgery, University of California at Los Angeles

SUMMARY HLA phenotypes were correlated with serum antibody titres to eight viruses in patients with multiple sclerosis and two matched control groups in the Orkney Islands. In patients, no specific HLA antigen was associated with increased or decreased viral titres. However, HLA-B7 was significantly correlated with higher measles titres in healthy controls. Furthermore, controls who had the HLA haplotype, B7, DW2 and B-cell 4, demonstrated significantly higher antibody titres to measles and rubella than controls without these determinants $(P<0.005)$. To determine the effect of age, sex, and other variables upon viral titres, regression analysis was undertaken. A significant proportion of measles titre variance in patients was explained by sex and clinical factors. Among normal controls, HLA determinants explained a significant amount of measles and rubella titre variance. These data suggest that viral titres in normal individuals are influenced by certain HLA antigens and give indirect evidence that another, as yet undefined, determinant in the histocompatibility complex governs the immune response.

Control of the immune response in man is related to the histocompatibility complex, located on chromosome 6 , that contains genes which produce human leucocyte antigens (HLA). ${ }^{1}$ Studies in mice indicate that immune response (Ir) genes of that complex are important in neoplasia and infection. ${ }^{23}$

Several theories have been put forward to try to explain the way in which HLA antigens determine the immune response: (1) genes of the HLA system serve as cell membrane receptors for infectious agents; (2) an infecting organism similar in structure to an HLA antigen is not recognised as foreign ('molecular mimicry'); (3) disease susceptibility genes are linked to the histocompatibility region; and (4) Ir genes linked to the histocompatibility system are involved in cell-mediated immunity and the production of $\mathrm{IgG}$ antibody. ${ }^{4}$

Efforts to define the relationship of multiple sclerosis (MS), the HLA antigens, and immune response derive from cumulative evidence indicating an interaction of a preponderance of exogenous factors over endogenous factors in pathogenesis. The development of MS has been related to an, as yet, undetermined viral infection of early life. ${ }^{5}$ A number of studies have shown that MS patients exhibit a heightened humoural response to measles and other viruses, while displaying a decreased cell-mediated immunity. ${ }^{8-8}$ Certain antigens of the histocompatibility complex are more common in MS patients than normal controls. In some populations, HLA-A3 (locus A), HLA-B7 (locus B), HLA-DW2 (locus D) and several B-cell alloantigens, presumed to be closely related to the D locus, are all associated with a higher risk of developing MS. ${ }^{9-12}$ Attempts to correlate HLA type and viral antibody titres in MS patients and controls have produced a bewildering array of conflicting reports.

In Los Angeles, MS patients with HLA-A3 had a significant elevation of antibody titres to measles compared with patients lacking this antigen. ${ }^{9}$

Jersild $e t$ al demonstrated that MS patients with HLA-A3, HLA-B7, and/or HLA-B18 had significantly higher measles titres compared with either patients who did not have these antigens or a group of controls who were not analysed by HLA type. ${ }^{10}$ An increased incidence of HLA-B7 was observed in 59 white male MS patients compared with a group of male blood donors in Minnesota. ${ }^{13}$ Elevated antibody titres to measles were also demonstrated in those patients who had the HLA-B7 antigen, compared with controls with this antigen.

On the other hand, Bertrams et al did not find that the presence of HLA-A3 and/or HLA-B7 was associated with increased measles titres, although titres were higher in MS patients than in controls. ${ }^{14}$ No significant difference in antibodies to measles 
virus by the haemagglutination inhibition method was demonstrated when geometric mean titres (GMT) of MS patients, optic neuritis patients, and controls were compared by Arnason et al. ${ }^{15}$ However, controls with HLA-A3 had a higher mean titre than controls without this antigen $(P<0 \cdot 05)$. Both male and female MS patients born in South Africa, an area of low MS risk, demonstrated higher measles antibody titres than controls; however, there was no association between HLA-A3 or HLA-B7 and antibody titres to measles in patients or controls. ${ }^{16}$ Associations of viral antibody titres with HLA-A3 are now considered less important than associations with locus $B$ and $D$ antigens. The D locus is thought to be closer to a postulated Ir gene. ${ }^{4}$

Although most of the analyses of HLA and viral titres have been carried out with measles titres, Lehrich and Arnason found that both MS patients and controls with HLA-A3 and/or HLA-B7 have significantly increased titres to herpes simplex types 1 and $2 .{ }^{17}$ They concluded that increased titres to several viruses among MS patients may be due to the presence of certain HLA types which produce a response to viral or central nervous system antigens that increase susceptibility to demyelinating disease.

An outstanding study conducted by Symington $e t$ al compared many indices of immune function in patients with MS, controls matched for age and sex, and patients with other disabling neurological diseases who were matched to the MS patients for age, sex, and duration of disease and type of disability. ${ }^{8}$ Serum antibody titres to rubella and measles viruses were higher in MS patients than both control groups. No significant increase in HLA-A3 and HLA-B7 types was found in patients compared with controls. Furthermore, no association between the HLA phenotypes and serum antibodies to measles was noted. The immunological profile of these MS patients suggested an enhanced humoural response to certain antigens and a depressed immune response, the latter attributable to the disabling effects of the disease. On the basis of their results, the authors suggested that the 'immunological fault' in MS should not be sought in the systemic circulation but in the neuraxis itself.

An extensive study of MS was conducted from 1974 to 1977 in the Orkney and Shetland Islands of Scotland, an area with the highest prevalence of MS ever reported. HLA typing was performed and serum antibody titres to 17 viruses were measured in patients and two carefully matched control groups. The correlation between disease, viral titres, and HLA type form the basis of this paper.

\section{Methods}

Blood specimens were obtained from patients and controls for HLA typing and serology. Because of poor cell viability, no HLA typing results are available from the Shetland Islands. For each patient, two controls were chosen, both of the same age and sex as the patient. The first was born in the same parish as the patient (parish control); the second was born in a parish not contiguous to that of the patient (discontiguous control). No controls were chosen for the three patients who were not born in Orkney. Details of patient ascertainment, diagnostic criteria, control selection, blood collection, storage, and serological testing are presented elsewhere. ${ }^{18} 19$ Serum antibody titres were measured for the following viruses: measles, rubella, echoviruses 4 and 9, Coxsackie B3 and B4, influenza A, mumps, varicella-zoster, Epstein-Barr, polioviruses 1, 2 and 3 , cytomegalovirus, herpes simplex 1 and 2 , and canine distemper. The majority of serum antibody titres to echoviruses 4 and 9 and Coxsackie viruses B3 and B4 were undetectable. Therefore, no correlations between these viruses and HLA determinants were attempted. In addition, only a small random sample of individuals was tested for antibodies to polioviruses 1, 2 and 3, Epstein-Barr virus, and canine distemper virus; comparisons between these viruses and HLA type were of little value.

Methods for determining HLA antigens have been described previously. ${ }^{20}$ Nomenclature of the HLA system used at the time of this investigation (1976) is used in this report.

STATISTICAL TESTING

Most of the comparisons between MS patients and controls in this study involved non-parametric procedures. The $\chi^{2}$ test, comparing the proportions of positive or negative titres or comparisons based on titre dilutions, and the Kolmogorov-Smirnov test of distribution were employed. The use of the more powerful parametric test, Student's t test, was restricted to cases where the distribution of titres was close to normal. For several viruses in this study, this criterion was not met. The distributions for varicella-zoster and cytomegalovirus were not normal, because a substantial proportion of cases had undetectable or trace titres.

Results for parish and discontiguous controls were combined. This approach appeared to be justified because analyses were based on grouped HLA types rather than individual matched-pair comparisons and because the parish and discontiguous controls were not expected to differ for any hereditary characteristic.

\section{Results}

HLA phenotypes were correlated with serum antibody titres to eight viruses in 51 MS patients and 95 controls. No specific antigen was associated with increased or decreased viral titres in patients. When 
patients and controls were compared for each HLA type, no significant comparisons at the 0.01 level resulted. When 20 antigens are correlated with antibody titres for eight viruses (160 separate comparisons), eight significant comparisons at the 0.05 level can be expected by chance alone.

\section{HLA TYPE B 7}

MS patients with HLA-B7 did not demonstrate increased measles titres compared with patients lacking this antigen (Table 1), confirming the work of other investigators. ${ }^{81416}$ However, controls showed a significant correlation between the presence of HLA-B7 and a higher measles titre $(P=0 \cdot 01){ }^{*}$ The elevated GMT for measles in HLA-B7 positive controls was the result, in large part, of titres of 1:64 (Table 1). No association with HLA-B7 and other viral antibody titres was found.

Table 1 Antibody titres to measles in Orkney MS patients and controls grouped by presence of $H L A-B 7$

\begin{tabular}{|c|c|c|c|c|}
\hline \multirow[b]{2}{*}{ Titre } & \multicolumn{2}{|c|}{$M S$ patients } & \multicolumn{2}{|l|}{ Controls } \\
\hline & $\begin{array}{l}H L A-B 7 \\
\text { pos }\end{array}$ & $\begin{array}{l}\text { HLA-B7 } \\
\text { neg }\end{array}$ & $\begin{array}{l}\text { HLA-B7 } \\
\text { pos }\end{array}$ & $\begin{array}{l}\text { HLA-B7 } \\
\text { neg }\end{array}$ \\
\hline Undetectable & 6 & 8 & 4 & 17 \\
\hline Trace & 2 & 1 & - & 4 \\
\hline $1 / 8$ & 2 & 10 & 6 & 16 \\
\hline $1 / 16$ & 4 & 5 & 5 & 13 \\
\hline $1 / 32$ & 2 & 4 & 3 & 6 \\
\hline $1 / 64$ & 1 & 2 & 10 & 1 \\
\hline Geometric mean titre & $7 \cdot 8$ & $8 \cdot 9$ & $18 \cdot 6$ & $7 \cdot 7$ \\
\hline
\end{tabular}

The HLA-B7 data were analysed by sex (Table 2 ). The highest frequency of HLA-B7 (53\%) was found in female MS patients. It was remarkable that HLA-B7 was associated consistently with decreased titres in female patients and increased titre levels in female controls for measles, herpes 1 and 2 , cytomegalovirus, and influenza A (Table 2). The difference is statistically significant for measles $(P<0.005)$. Geometric mean titres were comparable in female HLA-B7 negative patients and female

" Mann-Whitney U test
HLA-B7 positive controls. Only two male MS patients were HLA-B7 (compared with 16 female patients $(P=0.002) ;{ }^{* *}$ therefore, correlations for all viruses in male patients positive for HLA-B7 were not of value. In female patients, the presence of HLA-A3 was also associated with decreased measles titres $(P=0.007),{ }^{* *}$ which may be the result of the strong linkage between HLA-A3 and HLA-B7.

\section{OTHER HLA TYPES}

The frequently linked locus $A$ and $B$ antigen haplotypes, HLA-A3-B7, HLA-A1-B8, and HLA-A2-B12, were not found to be associated with different titre levels in either patient or control groups. DW2 and B-cell 4 also showed a strong association with viral titres in female controls because of their strong linkage with HLA-B7. No association between DW2, B-cell 4 and viral titres was found among MS patients, without regard to sex.

\section{REGRESSION ANALYSES}

Because of the possible influence of other factors on viral titres, regression analyses were carried out to determine the relative contribution of selected independent variables in explaining titre variance for the eight viruses. These variables included age, sex, laboratory testing variability, clinical factors (age at onset of multiple sclerosis, disease activity within the past year, and temporal course of disease), and the presence of the HLA determinants HLA-B7, DW2, and B-cell 4.

Among MS patients, a significant proportion of measles titre variance was explained by sex and clinical factors (Table 3). Of minor importance were age, laboratory variability, or the HLA determinants. However, among normal controls the HLA determinants (especially HLA-B7) explained a significant amount of measles titre variance, while age, sex, and laboratory variability contributed relatively little to the overall regression.

** Fisher exact probability test

Table 2 Antibody titres to eight viruses in MS patients and controls in Orkney by sex and HLA Type B7

GEOMETRIC MEAN TITRES

\begin{tabular}{|c|c|c|c|c|c|c|c|c|}
\hline \multirow[b]{2}{*}{ Virus } & \multicolumn{4}{|l|}{$M S$ patients } & \multicolumn{4}{|l|}{ Controls } \\
\hline & $\begin{array}{l}\text { HLA-B7+ } \\
\text { Male* }\end{array}$ & Female & $\begin{array}{l}\text { HLA-B7- } \\
\text { Male }\end{array}$ & Female & $\begin{array}{l}\text { HLA-B7+ } \\
\text { Male }\end{array}$ & Female & $\begin{array}{l}\text { HLA-B7- } \\
\text { Male }\end{array}$ & Female \\
\hline $\begin{array}{l}\text { Measles } \\
\text { Rubella } \\
\text { Herpes } 1 \\
\text { Herpes } 2 \\
\text { Cytomegalo-virus } \\
\text { Mumps } \\
\text { Varicella } \\
\text { Influenza A }\end{array}$ & & $\begin{array}{r}8 \cdot 1 \\
39 \cdot 4 \\
61 \cdot 0 \\
19 \cdot 3 \\
34 \cdot 8 \\
3 \cdot 4 \\
2 \cdot 9 \\
6 \cdot 7\end{array}$ & \begin{tabular}{r|}
$5 \cdot 7$ \\
$17 \cdot 8$ \\
$102 \cdot 5$ \\
$32 \cdot 0$ \\
$14 \cdot 2$ \\
$2 \cdot 1$ \\
$1 \cdot 8$ \\
$8 \cdot 2$
\end{tabular} & $\begin{array}{r}19 \cdot 3 \\
49 \cdot 8 \\
93 \cdot 1 \\
25 \cdot 8 \\
57 \cdot 7 \\
3 \cdot 6 \\
1 \cdot 9 \\
13 \cdot 2\end{array}$ & \begin{tabular}{r|}
$14 \cdot 3$ \\
$25 \cdot 8$ \\
$19 \cdot 8$ \\
$12 \cdot 3$ \\
$4 \cdot 9$ \\
$3 \cdot 3$ \\
$2 \cdot 7$ \\
$10 \cdot 3$
\end{tabular} & $\begin{array}{r}23 \cdot 4 \\
37 \cdot 5 \\
141 \cdot 0 \\
30 \cdot 5 \\
46 \cdot 5 \\
3 \cdot 6 \\
4 \cdot 4 \\
12 \cdot 1\end{array}$ & $\begin{array}{r}7 \cdot 6 \\
19 \cdot 5 \\
124 \cdot 5 \\
32 \cdot 9 \\
7 \cdot 8 \\
3 \cdot 5 \\
2 \cdot 3 \\
10 \cdot 0\end{array}$ & $\begin{array}{r}7 \cdot 7 \\
17 \cdot 2 \\
33 \cdot 4 \\
13 \cdot 3 \\
10 \cdot 1 \\
3 \cdot 1 \\
2 \cdot 6 \\
8 \cdot 3\end{array}$ \\
\hline
\end{tabular}

- Two cases only. 
Table 3 Regression analysis of measles titres in MS patients and controls in the Orkney Islands

(a) MS patients

\begin{tabular}{|c|c|c|c|c|}
\hline $\begin{array}{l}\text { Independent } \\
\text { variables }\end{array}$ & $\begin{array}{l}\text { Proportion of } \\
\text { measles variance } \\
\text { explained }\end{array}$ & $F$ & $(D F)$ & $P$ value \\
\hline $\begin{array}{l}\text { Sex } \\
\text { Age } \\
\text { Laboratory variability } \\
\text { HLA determinants } \\
\text { HLA-B7 } \\
\text { DW } 2 \\
\text { B-cell } 4 \\
\text { Clinical factors } \\
\text { Age at onset } \\
\text { Disease activity } \\
\text { Temporal course }\end{array}$ & $\begin{array}{l}0.16 \\
0.00 \\
0.01 \\
0.07 \\
0.01 \\
0.01 \\
0.05 \\
0.23 \\
0.10 \\
0.06 \\
0.06\end{array}$ & $\begin{array}{r}11 \cdot 98 \\
0.11 \\
1.09 \\
1 \cdot 74 \\
0.65 \\
0.79 \\
3.79 \\
5.02 \\
6.70 \\
4.93 \\
4.91\end{array}$ & $\begin{array}{l}(1,40) \\
(1,40) \\
(1,40) \\
(3,40) \\
(1,40) \\
(1,40) \\
(1,40) \\
(3,34) \\
(1,34) \\
(1,40) \\
(1,40)\end{array}$ & $\begin{array}{l}<0.005 \\
\text { N.S. } \\
\text { N.S. } \\
\text { N.S. } \\
\text { N.S. } \\
\text { N.S. } \\
<0.10 \\
<0.01 \\
<0.025 \\
<0.05 \\
<0.05\end{array}$ \\
\hline Total $\mathbf{R}^{2}$ & 0.47 & 3.41 & $(9,34)$ & $<0.005$ \\
\hline \multicolumn{5}{|l|}{ (b) Controls } \\
\hline Total $\mathbf{R}^{2}$ & 0.25 & $4 \cdot 24$ & $(6,75)$ & $<0.005$ \\
\hline
\end{tabular}

Table 4 Antibody titres to measles in Orkney controls grouped by the presence or absence of HLA-B7, DW2, and B-cell 4

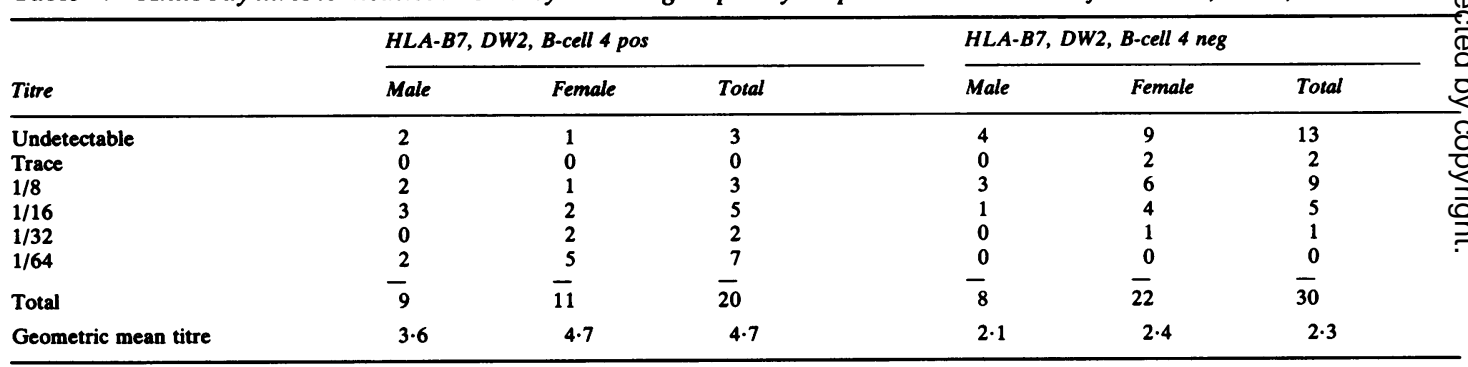

(K-S test, $\chi^{2}=12 \cdot 0,2$ df, $\left.P<0 \cdot 005\right)$

Table 5 Antibody titres to Rubella in Orkney controls grouped by the presence or absence of HLA-B7, DW2, and B-cell 4

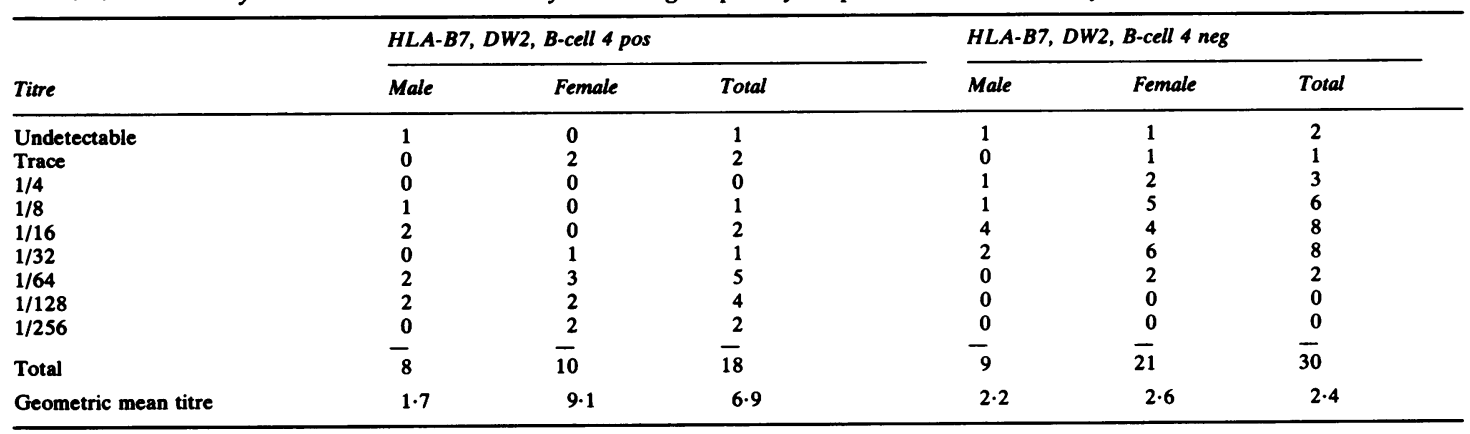

(K-S test, $x^{2}=13.32,2$ df, $P<0.005$ )

The regression analysis for rubella titre variance was also significant in controls $(F=2,90, \mathrm{df}=5,76$; $P<0.025$ ) and, as with the measles regression, most of the variation was explained by the HLA determinants. For the other viruses tested no other regressions of independent variables were significant for either MS patients or controls.

We have previously reported that the presence of HLA-B7, DW2, and B-cell 4 combined is significantly more common in controls than 
patients. ${ }^{20}$ No associations between HLA-B7, DW2, and B-cell 4 and viral titres were found in patients. However, controls who had HLA-B7, DW2, and B-cell 4 had significantly higher measles and rubella titres than those found in controls who had none of these determinants $(P<0 \cdot 005)^{*}$ (Tables 4 and 5). All three were shown to be important in the regression analysis (see Table $3 \mathrm{~b}$ for measles) in descending order: HLA-B7, DW2, and B-cell 4.

\section{Discussion}

HLA DETERMINANTS AND VIRAL TITRES IN NORMAL CONTROLS

The data presented here support the hypothesis that viral titres in normal (control) individuals vary significantly depending on the presence or absence of the cellular antigens, HLA-B7, DW2, and B-cell 4. Furthermore, the evidence suggests that another determinant exists which has a more direct effect on antibody response. This conclusion is derived from two observations in controls: (1) that higher titres to measles and rubella viruses were found when all three of these determinants were present (Tables 4 and 5); and (2) that the regression analysis in controls (Table 3b) implicates each of the three separately as important in influencing measles and rubella antibody titres. Linkage of each of these determinants to another gene (a postulated Ir gene) is supported.

\section{HLA ANTIGENS IN MS}

The results obtained here conflict with those obtained in previous studies. ${ }^{9}{ }^{1013}$ No specific HLA antigen was increased in MS patients in this study although female patients had the highest incidence of HLA-B7. ${ }^{20}$ It should be pointed out that this study, unlike most others, attempted complete ascertainment of MS patients in a defined, somewhat isolated, population. Previous studies have selected patients from registries, neurological clinics, or hospital services. Such patient groups may contain a disproportionate number of MS patients with classical, relapsing-remitting course and early onset. It is suggested that cases characterised by non-classical course and late onset may have been systematically excluded from studies of HLA. Twenty-two per cent of the patients in Orkney had non-classical disease and generally later onset of MS.

It is of particular interest, therefore, that this study demonstrated an apparent immunological role of HLA in controls, which was not present in the patients. The difference between controls and patients was also displayed in the response of controls to the mixed lymphocyte culture test, which was

\footnotetext{
* K-S test
}

strongly negative or positive in most instances, while MS patients fell to a much greater degree in the equivocal range. ${ }^{20}$ These findings should be kept in mind when interpreting the association of specific HLA determinants and serum antibody levels to measles and rubella in the controls but not among the patients. If the association seen among controls represents a normal immunological function, then the absence of the association among patients may represent an immunological dysfunction.

\section{SEX}

Correlations between viral titres and HLA-B7 were carried out only for female patients, because only two of the male patients were positive for HLA-B7. Sex has been identified as a critical factor in the relationship between graft survival and HLA matching of donor and recipient at the $A$ and $B$ loci. ${ }^{21}$ Graft survival was positively associated with the number of matched antigens only in male recipients but not in female recipients. This difference of response between males and females remains unexplained and in only a few studies of MS and HLA determinants has the relationship been subjected to analysis. ${ }^{22} 2324$ The failure of most studies of HLA to analyse results by sex is surprising in the light of the predominance of females among MS patients and the high correlation between HLA-B8 in females with myasthenia gravis. ${ }^{25}$ In this study, the frequency of HLA-B7 was higher in female patients $(53 \%)$ than in female controls (37\%).

The original observations that increased measles titres occur in MS patients with HLA-A3 or HLA-B7 as compared with controls have not been confirmed in six studies. ${ }^{16}$ None thus far, however, has shown the reverse relationship demonstrated by this study which shows that titres to measles and other viruses are lower in female patients with HLA-B7 than in female controls with HLA-B7. The incidence of HLA-B7 is increased in MS patients only in certain ethnic groups, mainly northern European, and even then only about $35 \%$ of patients possess that antigen compared with about $25 \%$ of controls in most studies. The majority of patients, therefore, are HLA-B7 negative. Measles titres in the general population are known to be higher in females than males. Therefore, female patients and HLA-B7 negative patients, both with higher titres, predominate in MS. These findings may account for the higher measles titres reported in MS patients as a group.

This study demonstrates a difference in response to viruses between patients and controls; a heightened response to measles is not related to HLA-B7 in patients but is clearly related to HLA-B7 in controls. The difference is related to sex in patients but not 
related to sex in controls. A linkage between immune response genes and the $\mathrm{X}$ chromosome has been demonstrated in mice by Mozes and Fuchs. ${ }^{26}$ The relationship between sex-dependent factors and MS is as yet unexplained.

This study was supported by the National Institute of Neurological and Communicative Disorders and Stroke Contract No. N01-NS-4-2321 and the National Multiple Sclerosis Society.

Reprints from Dr. David C. Poskanzer, Neurology Service, Massachusetts General Hospital, 32 Fruit Street, Boston, MA 02114, USA.

\section{References}

${ }^{1}$ McDevitt HO, Bodmer WF. HL-A, immune response genes, and disease. Lancet 1974; i: 1269-75, 1974.

${ }^{2}$ Lilly F, Boyse EA, Old LJ. Genetic basis of susceptibility to viral leukaemogenesis. Lancet 1964; ii: 1207-9.

${ }^{3}$ Oldstone MBA, Dixon FJ, Mitchell GF, McDevitt HO. Histocompatibility-linked genetic control of disease susceptibility. Murine lymphocytic choriomeningitis virus infection. J Exp Med 1973; 137: 1201-12.

${ }^{4}$ Svejgaard A. HLA factors and immune function. Acta Endocrinol 1976; 83, suppl 205: 77-83.

${ }^{5}$ Poskanzer DC. Epidemiological evidence for a viral etiology for multiple sclerosis. In: Slow, Latent and Temperate Virus Infections. Washington DC: US Department of Health, Education, and Welfare, 1965: 55-63.

${ }^{6}$ Brody JA, Sever JL, Henson TE. Virus antibody titers in multiple sclerosis patients, siblings, and controls. JAMA 1971; 216: 1441-6.

${ }^{7}$ Sever JL, Kurtzke JF, Alter M et al. Virus antibodies and multiple sclerosis. Arch Neurol 1971; 24: 489-94.

${ }^{8}$ Symington GR, Mackay IR, Whittingham S, White J, Buckley JD. A 'profile' of immune responsiveness in multiple sclerosis. Clin Exp Immunol 1978; 31: 141-9.

${ }^{9}$ Myers LW, Ellison GW, Fewster ME, Terasaki PI, Opelz G. HLA and the immune response to measles in multiple sclerosis. Neurology 1976; 26, part 2: 54-5.

${ }^{\circ}$ Jersild C, Svejgaard A, Fog T, Ammitzboll T. HL-A antigens and diseases. I. Multiple sclerosis. Tissue Antigens 1973; 3: 243-50.
${ }^{11}$ Opelz G, Terasaki P, Myers L et al. The association of HLA antigens A3, B7, and DW2 with 330 multiple sclerosis patients in the United States. Tissue Antigens 1977; 9: 54-8.

${ }^{12}$ Compston DAS, Batchelor JR, McDonald WI. B-lymphocyte alloantigens associated with multiple sclerosis. Lancet 1976; ii: 1261-5.

${ }^{13}$ Whitaker JN, Herrmann KL, Rogentine N, Stein SF, Kollins LL. Immunogenetic analysis and serum viral antibody titers in multiple sclerosis. Arch Neurol 1976; 33: $399-403$.

${ }^{14}$ Bertrams J, von Fisenne E, Hoher PG, Kuwert E. Lack of association between HL-A antigens and measles antibody in multiple sclerosis. Lancet 1973; ii: 441.

${ }^{15}$ Arnason BGW, Fuller TC, Lehrich JR, Wray SH. Histocompatibility types and measles antibodies in multiple sclerosis and optic neuritis. J Neurol Sci 1974; 22: 419-28.

${ }^{16}$ Fewster ME, Arnes FR, Botha MC. Measles antibodies and histocompatibility types in multiple sclerosis. $J$ Neurol Sci 1979; 43: 19-26.

${ }^{17}$ Lehrich JR, Arnason BGW. Histocompatibility types and viral antibodies. Arch Neurol 1976; 33: 404-5.

${ }^{18}$ Poskanzer DC, Prenney LB, Sheridan JL, YonKondy J. Multiple sclerosis in the Orkney and Shetland Islands. I: Epidemiology, clinical factors, and methodology. $J$ Epidemiol Community Health 1980; 34: 229-39.

${ }^{19}$ Poskanzer DC, Sever JL, Sheridan JL, Prenney LB. Multiple sclerosis in the Orkney and Shetland Islands. IV: Viral antibody titres and viral infections. $J$ Epidemiol Community Health 1980; 34: 258-64.

${ }^{20}$ Poskanzer DC, Terasaki PI, Prenney LB, Sheridan JL, Park M. Multiple sclerosis in the Orkney and Shetland Islands. III: Histocompatibility determinants. $J$ Epidemiol Community Health 1980; 34: 253-7.

${ }^{21} \mathrm{Opelz} G$, Terasaki PI. Influence of sex onhistocompatibility matching in renal transplantation. Lancet 1977; ii: 419-21.

${ }^{22}$ Paty DW, Furesz J, Boucher DW, Rand CG, Stiller CR Measles antibodies as related to HL-A types in multiple sclerosis. Neurology 1976; 27: 651-5.

${ }^{23}$ Visscher BR, Myers LW, Ellison GW, et al. HLA types and immunity in multiple sclerosis. Neurology 1979; 29: 1561-5.

${ }^{24}$ Fewster ME, Myers LW, Ellison GW, Walford RL. Histocompatibility types and measles antibodies in multiple sclerosis. J Neurol Sci 1977; 34: 287-96.

${ }^{25}$ Fritze D, Herrmann C Jr, Naeim F, Smith GS, Walford RL. HL-A antigens in myasthenia gravis. Lancet 1974; ii: 43 .

${ }^{26}$ Mozes E, Fuchs S. Linkage between immune response potential to DNA and X chromosomes. Nature 1974; 249: $167-8$. 